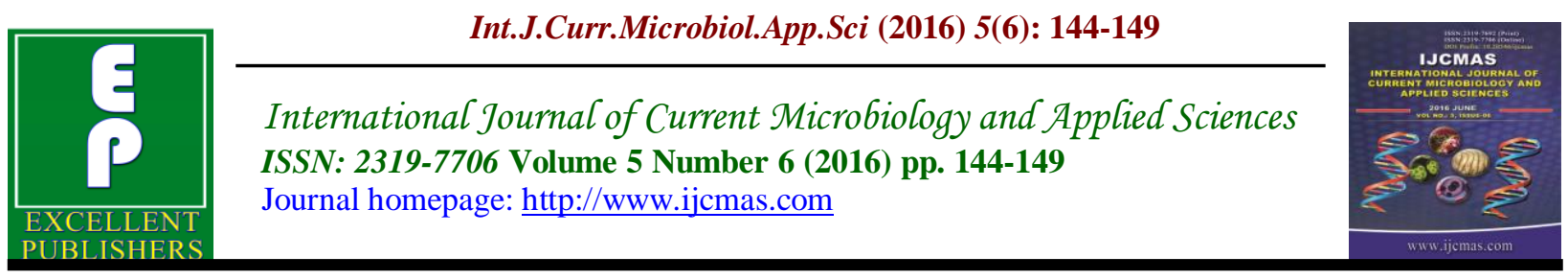

Original Research Article

http://dx.doi.org/10.20546/ijcmas.2016.506.018

\title{
DNA Quantification Studies of Selaginella bryopteris (L.) Bak. Genotypes in Telangana, India
}

\author{
P. Rupa* and N. Lakshmi Bhavani \\ Plant Tissue Culture and Molecular Genetics Lab, Department of Botany, \\ University College of Science, Saifabad, Osmania University, Hyderabad 500004, India \\ *Corresponding author
}

\begin{tabular}{|c|c|}
\hline & A B S T R A C T \\
\hline Keywords & \multirow{9}{*}{$\begin{array}{l}\text { Selaginella bryopteris (L.)Bak. is a resurrection plant with unique desiccation } \\
\text { tolerance character. It is lithophytic, heterosporous, first vascular and potent } \\
\text { medicinal herb belonging to the family Selaginellaceae. Selaginella bryopteris (L.) } \\
\text { Bak. genotypes were identified, collected and preserved from various hilly regions } \\
\text { of Rangareddy, Medak, Mahaboobnagar, Karimnagar and Warangal districts of } \\
\text { Telangana, India. Collected plant genotypes were used to screen the genomic DNA, } \\
\text { quantification and their analysis. For the DNA isolation modified CTAB method of } \\
\text { Murray and Thomson was used. Quantity and quality of genomic DNA of } \\
\text { Selaginella bryopteris (L.)Bak. genotypes were assessed by spectrophotometry and } \\
\text { gel electrophoresis methods. The range of DNA Quantification values ( } 251 \mathrm{ng} / \mu 1 \text { to } \\
879 \mathrm{ng} / \mu \mathrm{l} \text { ) and DNA Purity index values (1.13 to } 2.37) \text { of Selaginella bryopteris } \\
\text { (L.) Bak. indicated the diversity among genotypes. }\end{array}$} \\
\hline & \\
\hline Bak., CTAB & \\
\hline method, DNA & \\
\hline $\begin{array}{l}\text { isolation and } \\
\text { Telangana. }\end{array}$ & \\
\hline Article Info & \\
\hline & \\
\hline 11 May 2016 & \\
\hline $\begin{array}{l}\text { Available Online: } \\
10 \text { June } 2016\end{array}$ & \\
\hline
\end{tabular}

\section{Introduction}

Arthur Garfit Alston was the first botanist to report Selaginella species from China and Philippines in the early years of 1930. Selaginella is the first vascular plant on the earth (Swetha Singh 2015). It has been existing from 300 million years (Reena Antony and Rini Thomas, 2011). Selaginella bryopteris (L.) Bak is an endomic pteridophytic species of India and Nepal distributed in warm hilly slopes between 400-1000 m altitudes (Swetha Singh 2015) and regions of Arawali Mountain (Sunitha Lahkar et al., 2015). It is commonly called as Sanjeevani booti.
Selaginella bryopteris (L.) Bak. is also called as spike moss, it grows in rocks, litter and their own dead tissue of organic matter (Sunitha Lahker et al., 2015). The plant has shown pharmalogical activities such as anti bacterial (Agarwal and Singh, 1999), anti protozoal (Kunert et al., 2008), anti inflammatory (Jitender malviya et al., 2012), anti stomachache (Pandey et al., 1993), anti stress and growth promoting activity (Sah et al., 2005).

Isolation of the DNA is the pre requisite step for molecular and genetic diversity studies. Several protocols available for DNA 
isolation especially for Sellaginella species are Sodium Dodecyl Sulphate method (SDS) of Dellaporta etal,.1983,Cetyl Tri Methyl Ammonium Bromide (CTAB) method of Murry and Thomson 1980, Doyle and Doyle (1987) and modified CTAB method of Rogers and Bendich 1994(Sanyantani Das et al., 2012).

CTAB method is simple, effective and most commonly used method (Pratibha Devi,2005) to isolate the genomic DNA from different plant tissues like cotton (Chandra shekar and Lakshmi Bhavani, 2012), Redsandar (Jyothi Chaithanya et al., 2013), ferns (Dempster et al., 1999) and Sellaginella species like S.delicatula, S.repanda, S.bryopteris, S.plana and S.monospora. (Sanyantani Das et al., 2012).

\section{Materials and Methods}

Fresh and healthy Selaginella bryopteris (L.) Bak. plant materials obtained from various hilly regions of Telangana state especially in the regions of Rangareddy, Medak, Mahaboobnagar, Karimnagar and Warangal districts in various seasons of the year was wrapped in aluminum foils and stored at $4{ }^{\circ} \mathrm{C}$ of temperature for future usages. For the present study fresh as well as frozen plant materials were used (table 1).

Total genomic DNA was extracted from Selaginella bryopteris(L.)Bak. plant material by CTAB method given by Murray \& Thompson (1980) with some modifications. Approximately $1 \mathrm{gm}$ of the sample was masticated to fine suspension with CTAB buffer $(100 \mathrm{mM}$ Tris, $20 \mathrm{mM}$ EDTA, 1.4M NaCl, 2\% CTAB, pH 8.0). The fine suspension was taken into $2 \mathrm{ml}$ eppendorf tubes and incubated in a water bath at $65^{\circ} \mathrm{C}$ for 40 minutes with intermittent mixing for every 5 minutes.
The incubated samples were allowed to attain room temperature and an equal volume of chloroform: isoamyl alcohol was added gently, mixed for 15 minutes and centrifuged at $10,000 \mathrm{rpm}$ for 10 minutes. The aqueous layer obtained is transferred to $1.5 \mathrm{ml}$ eppendorf tubes. To these tubes containing supernatant, an equal volume of chilled isopropanol was added and gently mixed by inverting the tube, incubated for 10 minutes in refrigerator and centrifuged at $12,000 \mathrm{rpm}$ for 10 minutes. The supernatant obtained is discarded and the pellet is washed with $70 \%$ ethanol followed by centrifugation at 8000rpm for 5 minutes. This ethanol and centrifugation step is repeated twice. The pellet is air dried and dissolved in sterile distilled water/ $\mathrm{T}_{10} \mathrm{E}_{1}$ buffer, where $T_{10} E_{1}$ buffer facilitates for longer storage whereas sterile distilled water for shorter storage. The samples were stored in $-20^{\circ} \mathrm{C}$ freezer for further use.

DNA quantification has been made by spectrophotometer which is a simple accurate and most popular method. Spectrophotmetric measurements indicate the amount of ultra violet irradiation absorbed by the bases of the nucleic acid (Pratibha Devi, 2005). Purines and pyrmidines in nucleic acid show absorption maximum around 260nm (dATP: 259nm, dCTP: $272 \mathrm{~nm}$, dTTP: $247 \mathrm{~nm}$ ) if the DNA sample is pure without significant contamination from proteins or organic solvents (Sambrook, 1989).

The amount of DNA can be quantified using the formula:

DNA concentration $(\mu \mathrm{g} / \mathrm{ml})=$

$\underline{\text { OD260 x } 100 \text { (dilution factor) } \times 50 \mu \mathrm{g} / \mathrm{ml}}$

Gel quantification is a technique used to estimate the size and quantity of DNA 
fragments in an agarose gel. The technique involves the comparison of a known quantity of DNA to an unknown quantity of DNA on an agarose gel.

\section{Results and Discussion}

The DNA quantification values of all the genotypes are calculated and presented in table 2 and plotted as graph and represented in graph (fig1). DNA purity was determined by using of the ratio of OD260/OD280 and presented in table 3. Pure samples of DNA and RNA have value of 1.8and 2 respectively (Pratibha Devi, 2005). The gel is stained with ethidium bromide and photographed. The brightness of a particular fragment, as well as the distance travelled, can be used to estimate the quantity and size of the DNA fragments (fig 2).

Table.1 The sampling locations and their GPS (Global Position System)

\begin{tabular}{|c|c|c|c|c|}
\hline $\begin{array}{l}\text { Sampling } \\
\text { site no. }\end{array}$ & $\begin{array}{l}\text { Sampling } \\
\text { site code }\end{array}$ & Location of Sampling & Latitude & Longitude \\
\hline 1 & KNR-1 & Shanigharam, Karimnagar(D) & $18^{0} 11^{\prime} 32.84^{\prime \prime} \mathrm{N}$ & $79^{0} 00^{\prime} 32.57^{\prime} \mathrm{E}$ \\
\hline 2 & KNR-2 & Lingannapet, Karimnagar(D) & $18^{0} 17^{\prime} 10.87^{\prime} \mathrm{N}$ & $78^{0} 35^{\prime} 05.48^{\prime \prime} \mathrm{E}$ \\
\hline 3 & MBNR-1 & Ippalpalle, Mahabubnagar(D) & $16^{0} 40^{\prime} 59.43^{\prime \prime} \mathrm{N}$ & $77^{0} 58^{\prime} 34.08^{\prime \prime} \mathrm{E}$ \\
\hline 4 & MDK-1 & Pullur, Medak(D) & $18^{0} 10^{\prime} 33.95^{\prime \prime} \mathrm{N}$ & $78^{0} 48^{\prime} 44.77^{\prime \prime} \mathrm{E}$ \\
\hline 5 & MDK-2 & Chandlapur, Medak(D) & $18^{0} 10^{\prime} 07.13^{\prime \prime} \mathrm{N}$ & $78^{0} 49^{\prime} 25.43^{\prime \prime} \mathrm{E}$ \\
\hline 6 & R.R-1 & Ekambbari, Rangareddy(D) & $17^{0} 82^{\prime} 09.31^{\prime \prime} \mathrm{N}$ & $77^{0} 27^{\prime} 10.22^{\prime \prime} \mathrm{E}$ \\
\hline 7 & R.R-2 & Kulakcharla, Rangareddy(D) & $17^{0} 01^{\prime} 13.37^{\prime \prime} \mathrm{N}$ & $77^{0} 54{ }^{\prime} 44.12^{\prime \prime} \mathrm{E}$ \\
\hline 8 & WL-2 & Komaravelli, Warangal(D) & $17^{0} 55^{\prime} 51.41^{\prime \prime} \mathrm{N}$ & $78^{0} 53^{\prime} 51.04^{\prime \prime} \mathrm{E}$ \\
\hline
\end{tabular}

Table.2 DNA Quantification values of Selaginella bryopteris (L.) Bak. genotypes obtained by U.V Spectrophotometer.

\begin{tabular}{|l|l|l|}
\hline S.No. & Samples & Concentration \\
\hline 1 & KNR-1 & $699 \mathrm{ng} / \mu \mathrm{l}$ \\
\hline 2 & KNR-2 & $257 \mathrm{ng} / \mu \mathrm{l}$ \\
\hline 3 & RR-1 & $691 \mathrm{ng} / \mu \mathrm{l}$ \\
\hline 4 & RR-2 & $879 \mathrm{ng} / \mu \mathrm{l}$ \\
\hline 5 & WL-1 & $487 \mathrm{ng} / \mu \mathrm{l}$ \\
\hline 6 & MBNR-1 & $377 \mathrm{ng} / \mu 1$ \\
\hline 7 & Medak-1 & $445 \mathrm{ng} / \mu 1$ \\
\hline 8 & Medak-2 & $325 \mathrm{ng} / \mu 1$ \\
\hline
\end{tabular}


Table.3 DNA Purity index (OD260/280) values of Selaginella bryopteris (L.) Bak. genotypes.

\begin{tabular}{|c|c|c|}
\hline S.NO & SAMPLES & OD260/280 \\
\hline 1 & KNR-1 & 1.85 \\
\hline 2 & KNR-2 & 1.52 \\
\hline 3 & RR-1 & 1.68 \\
\hline 4 & RR-2 & 1.13 \\
\hline 5 & WL-1 & 1.49 \\
\hline 6 & MBNR-1 & 1.83 \\
\hline 7 & Medak-1 & 1.79 \\
\hline 8 & Medak-2 & 2.37 \\
\hline
\end{tabular}

Fig.1 Graphical representation of DNA Quantification values of Selaginella bryopteris (L.) Bak. genotypes.

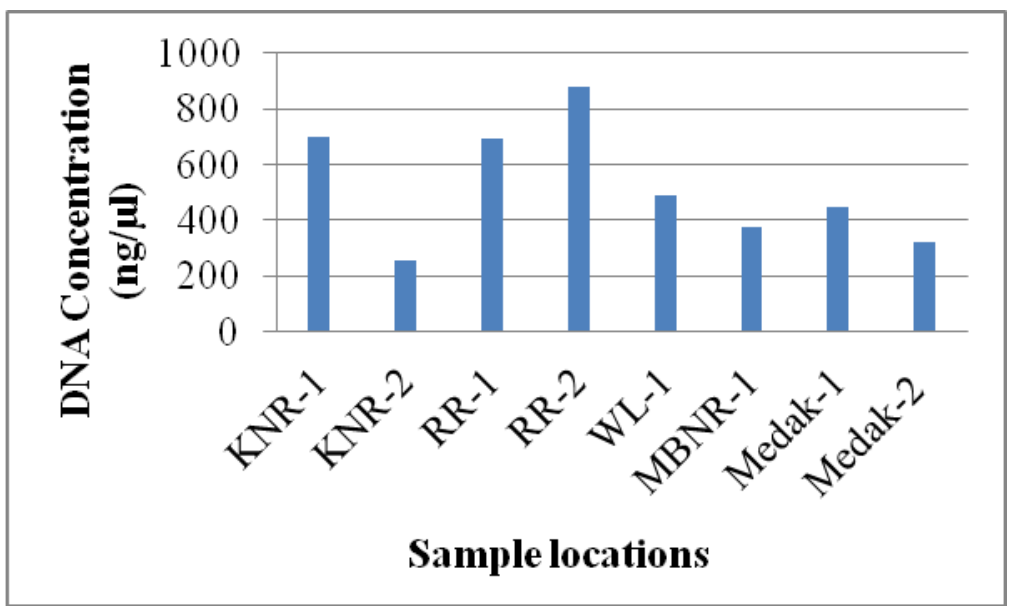

Fig.2 Gel pictures of Selaginella bryopteris (L.) Bak. Genotypes.

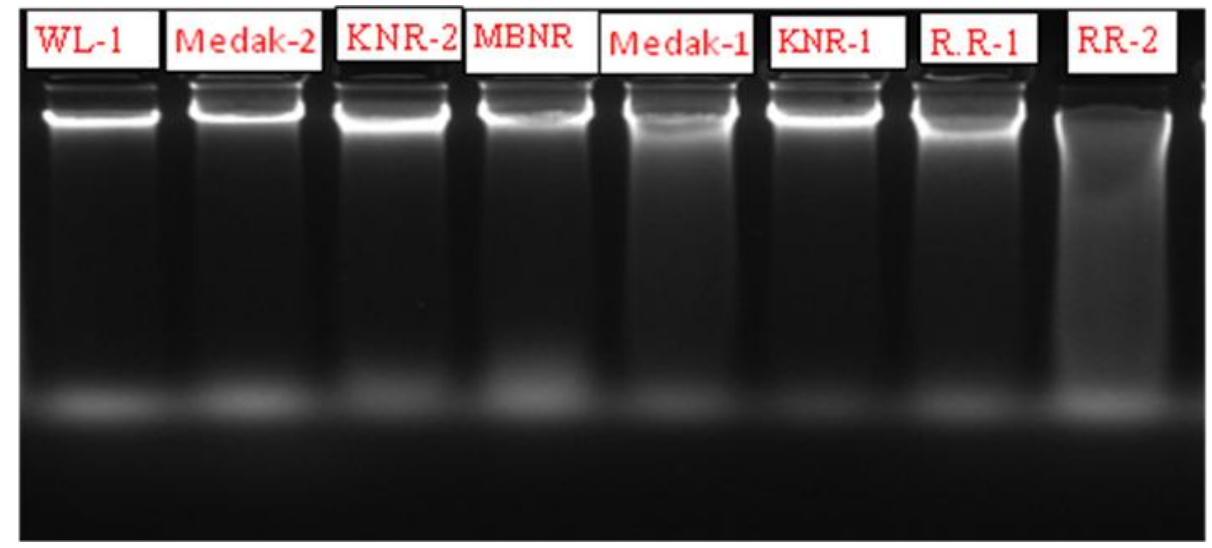


In conclusion, the main objective of the present study is the isolation, quantification and purity check of the genomic DNA of eight genotypes from various districts in Telangana region of Selaginella bryopteris (L.) Bak. The DNA quantification studies emphasized that the yield of DNA ranged from $251 \mathrm{ng} / \mu 1$ to $879 \mathrm{ng} / \mu \mathrm{l}$. The highest $(879 \mathrm{ng} / \mu \mathrm{l})$ and the lowest $(251 \mathrm{ng} / \mu \mathrm{l})$ DNA yield are achieved by R.R-2 and KNR-2 respectively. Purity index was checked by taking the ratio of OD260/OD280.The present study revealed that DNA purity of Selaginella bryopteris (L.)Bak. genotypes ranged from 1.13 to 2.37. The quantity and purity of DNA of Selaginella bryopteris (L.) Bak. genotypes have shown greater variation from one place to another.

\section{References}

Agarwal, S.S., Singh, V.K. 1999. Immuno modulators, A Review of studies on Indian Medicinal Plants and Synthetic Peptides: Part1.Med. Plants, 65(3\&4): 179-204.

Chandrashekar, R., N. Lakshmi Bhavani. 2012. DNA Analysis of Gossypium Varieties of Andhra Pradesh, Ad. Plant Sci., 25(11): 759-760.

Dampster, E.L., K.V. Pryor, D. Francis, J.E. Young, H.J. Rogers. 1999. Rapid DNA extraction from Ferns for PCR based analysis. BioTechniques, 27: 66-68.

Dellaporta, S.L., Wood, J., Hicks, J.B. 1983. A plant DNA mini preparation version II. Plant Mol. Biol. Reporter, 1: 19-21.

Doyle, J.J., J.L. Doyle. 1987. A rapid DNA isolation procedure for small quantities of fresh leaf tissue. Phyto Chem. Bull., 9: 11-15.

Jitender Malviya, Vaibhavi Joshi, Kiransingh. 2014. Antimicrobial activity of some -medicinal Plants used by Baiga Tribes from Amarkantak, India, Adv. Life Sci. Technol., 12: 128-129.

Jyothi Chaitanya, P.R., Chandrashekar, N. Lakshmi Bhavani. 2014. Isolation of Pterocarpus santalinus L. genomic DNA for quality check and quantification with reference to Telangana region, Andhra Pradesh, India, Ind. J. Sci., 8(19): 21-24.

Kunert, O., Swamy, R.C,. Kaiser, M., Presser, A., Buzzi, S., Rao, A.V. 2008. Anti plasmodial and leishmanicidal activity of bioflavonoids from Indian Selaginella bryopteris, Phyto Chem. Lett., 1(4): 171-174.

Murry, M., W.F. Thompson. 1980. Rapid isolation of molecular weight plant DNA, Nucleic acid, 8: 4321-5.

Pandey vivek, Sanjay Ranjan, Farah Deeba, Ashutosh, K., Pandey, Ruchi Singh, Pramod, A., Shirke, Uday, V., Pathre. 2010. Desiccaton -induced physiological and biochemical changes in resurrection plant, Selaginella bryopteris. J. Plant Physiol., 1351-1359.

Pratibha Devi. 2005. Principles and Methods of Plant Molecular Biology, Biochemistry and Genetics, ISBN No.:81-7754-051-3.

Reena Antony, Rini Thomas. 2011. A mini review on medicinal properties of the resurrecting plant Selaginella bryopteris (Sanjeevani); Int. J. Pharmacy and Life sci., Vol. 2 Issue 7, p933.

Rogers, S.O., Bendich, A.J. 1988. Extraction of DNA from plant tissues. In: Gelvin SB, Schilperoort RA (eds) Plant Molecular Biology Manual, pp A6: 1-10. Boston, MA: Kluwer Academic Publishers.

Sah, N.K., Singh, S.N.P., Sahdev, S., Banerji, S., Jha, V., Khan, Z., 
Hasnain, S.E. 2005. Indian herb sanjeevani (Selaginellabryopteris) can promote growth and protect against heat shock and apoptotic activities of ultraviolet and oxidative stress. J. Biosci., 30(4): 499-505.

Sambrook Joseph, Michael, R., Green. 1989. Molecular cloning-A Laboratory manual $2^{\text {nd }}$ Ed. Cold Spring Harbor Laboratory press, Cold Spring Harbor, Newyork.

Sayantani, Das, Maumita Bandyopadhyay, Subir Bera. 2012. Optimization of
Protocol for Isolation of Genomic DNA from Leaves of Selaginella Species Suitable for RAPD Analysis and Study of Their Gene Variation, American Fern J., 102(1): 47-54. Shweta Singh, Rita Singh. 2015. Int. J. Pharma. Sci. Res., Vol. 6(1): 50-56. Sunitha Lahkar, Pallab Kalita, Arpita Chakraborty. 2015. American J. Pharm. Health Res., 3(2): ISSN: 2321-3647.

\section{How to cite this article:}

Rupa, P. and Lakshmi Bhavani, N. 2016. DNA Quantification Studies of Selaginella bryopteris (L.) Bak. Genotypes in Telangana, India. Int.J.Curr.Microbiol.App.Sci. 5(6): 144149. doi: http://dx.doi.org/10.20546/ijcmas.2016.506.018 